International Migration and the Change of Women's Position among Left Behind in Rural Bangladesh

Abdullahel Hadi 


\title{
Abstract \\ International Migration and the Change of Women's Position among Left Behind in Rural Bangladesh
}

\begin{abstract}
While the impact of remittances on the economic condition of sending communities has received much attention, the effects of international migration on women's position among the left-behind have not been adequately explored. This paper examines the changes of the left behind women's position at the family level as a result of the migration of adult men to overseas. Data came from a demographic surveillance system covering 70 villages in Bangladesh. All migrant families having at least one male member working abroad for more than six months were identified in the study villages in 1996. A comparable number of non-migrant families were selected at random from the same villages to yield a total sample of 1,030 families. In-depth interviews were conducted with adult women of the sample families. Findings reveal that the overseas migration of adult males has a significant positive association with women's decision making capacity and education of girls in the migrant families. The remittances as well as the influence of secular values have reduced the practice of dowry in marriages. Multivariate analysis suggests not only that remittances have increased the financial capacity of the migrant families, but also that secular influences from overseas might have modified women's position when the role of other socio-economic factors are controlled. The study concludes that overseas migration of adult men can create a context for change of women's position in the traditional communities.
\end{abstract}

Keywords: International migration, decision-making, practice of dowry, Bangladesh 


\section{INTRODUCTION}

Compared to earlier permanent moves, contemporary international migration is primarily a 'south-north' temporary flow of labourers (United Nations, 1985) although the migrants include a wide spectrum of population from high skilled professionals to low paid workers. South-north migration not only promotes large inflows of remittance that stimulate economic growth in the south (Islam et al., 1987; Russell, 1997) but helps reducing poverty at the sending communities (Russell, 1997). While the role of remittances on economic development of the sending communities has received much attention, the social and cultural consequences of international migration on the left-behind women have not adequately explored (Hadi, 1999; Gardner, 1995).

In many cases, overseas migration results in the absence of adult men in the families. The left behind women have to adjust with such situation and, as a result, their role and status often undergo change. The adjustment process depends upon several factors such as their relationship with the migrants, the length of stay of the migrants in abroad and the sociocultural context where they live (Hugo, 1997). One direct result of male migration is the change in age and sex structure of the sending communities (Davin, 1998) and headship of nuclear families (Islam et al., 1987). Women are generally capable to adapt with the new situation and manage the household chores in their husband's absence (Colfer, 1985). This notion is considered ill-conceived by some who argue that women's autonomy and de facto headship is rather a fiction (Dawson, 1995\%).

The possible pathways through which international migration influences women's position are not clearly known. The flow of remittances along with the diffusion of secular ideas ${ }^{1}$ are expected to enhance the standard of living of the left behind women and provide greater access to resources that subsequently create an enable condition for them to change their position. The change of women's position may result in greater mobility, reduce dependence on traditional patrons and increase self-confidence (Hugo, 1997). On the other hand, it is quite possible that the presumed change of women's role is only temporary and a reflection of the changed condition where they are forced to live and adjust.

\section{Out-migration from Bangladesh}

A considerable number of Bangladeshis are living abroad for quite a long time (Hadi, 1999). It is not known exactly when the Bangladeshis began to migrate to overseas. The first documented migrants were a small group of unskilled labourers who moved to the Britain in the late nineteenth century (Hadi, 1999; Islam et al., 1987). Since then, the Bangladeshi labourers, although smaller in scale, continued to migrate primarily to the British islands till the beginning of World War II. During fifties, a large number of semiskilled labourers had the opportunity to move to Europe when the British government introduced employment vouchers to foreign workers (Hadi, 1999). But the flow of migration from Bangladesh to 
Europe fell considerably when the European governments restricted the entry of overseas workers to Europe. During 1970s and 1980s, a large number of labourers migrated to Western Europe, particularly to Germany and Italy, a significant proportion of whom ultimately moved to North America. Also, the poor economic condition of Bangladesh forced the young workforce to seek employment opportunities in other destinations in Asia and the Middle East.

The contribution of remittance in raising living standard among the left behind in Bangladesh is well known (Hadi, 1999; Islam et al., 1987). Given the improvement of air transportation, huge number of overseas Bangladeshi migrants frequently visit their left behind family members. As a result, the diffusion of secular values from overseas has also significantly increased. The left behind family members adjust not only to the absence of family members but also to the influences of remittance, household goods, attitudes and behaviours transmitted by the migrants (Hugo, 1997). Given this backdrop, the study examines the contribution of international migration of adult men in changing women's position ${ }^{2}$ of the left behind in rural Bangladesh. Three aspects of women's position viz. household decision making capacity, enrollment of girls in school and the practice of dowry in marriages are considered for this research recognising that such a definition reflects only a part of women's position.

\section{DATA AND METHODS}

\section{Data}

Migration data are rarely collected in Bangladesh. Official statistics of the manpower export are either incomplete or inaccurate although the first documented migration from Bangladesh began in the last century (Islam et al., 1987; Hadi, 1999). Data for this study were collected from a demographic surveillance system covering 70 villages located in ten regions of rural Bangladesh. A complete enumeration of the study villages in 1996 revealed that migrant families were concentrated largely in greater Sylhet and Chittagong districts in Bangladesh. Migrant families are defined as families where at least one member either had been living or returned home after living in a foreign land for at least six months. A total of 530 migrant families were identified in the study villages of which information from 515 families were successfully collected. A comparison group, 515 non-migrant families was also selected at random from the same villages to yield a total of 1,030 sample families for the study. One married woman was selected again from each sample family for interview. Given the nature of the study, in-depth interviews were considered appropriate that provided information about women's decision making role, educational aspiration for girls and the practice of dowry in marriages in addition to basic demographic and socio-economic characteristics of the families. 


\section{Model specification}

Overseas migration is viewed both as the cause and effect of structural change in the less developed countries (Jones and Pardthaisong, 1999). This study considers the change of women's position as the effect of overseas migration of their family members. As the study focuses on women's position of the left-behind families, the unit of analysis is considered the 'family'. The sample families are categorised into non-migrant, migrant for $<5$ years. and migrant for 5 years or more. The study assumes that the international migration from Bangladesh villages significantly improves the position of left-behind women. Three indicators of women's position are conceptualised in this research: a) decision making capacity ${ }^{3}$ that measures women's status in the family, b) education for girls ${ }^{4}$ that refers to the behaviour toward gender equity and c) the practice of dowry, a negative scenario from the secular perspective indicating the prevalence of patriarchy and gender inequality.

In designing the analytical model, three dichotomised dependent variables are used. A number of confounding variables such as age and years of schooling of women, amount of land owned and religious belief are considered to influence the effects of migration on the change of women's position. The model employed is of the following form:

$$
\ln \frac{(p)}{(1-p)}=\alpha+\sum_{i=1}^{k}\left(\beta_{i}^{*} x i\right)
$$

where $\mathrm{p}$ is the probability that women's decision making in the family (or education for girls) is positive (or negative in case of the practice of dowry), $\alpha, \beta_{i}$ are estimated regression coefficients; and $x_{i}$ are the explanatory variables. In the analysis, log odds ratios of explanatory variables in the models are estimated to predict the indicators of women's position. This helps to understand the percentage change in the odds associated with each unit change in the explanatory variables.

\section{Analytical procedure}

The analysis begins with a description of the socio-demographic characteristics of women and families by migration status. Then, the differences in three indicators of women's position between migrant and nonmigrant families by socio-economic characteristics are presented. Finally, the net effects of migration on the indicators of women's position are assessed. In the absence of longitudinal data, this study has opted a cross sectional approach. Thus, the results may generate biased estimates of the impact of migration on women's position because families that are relatively better-off may be more likely than others to send their members to overseas. Considering the change of women's position as the outcome, multivariate analyses have been used to control the effects of several sociodemographic confounding factors. Despite 
these steps, the estimated effects of the migration on women's position may distort the findings and the conclusions drawn from them.

Table 1. Background characteristics of the study population by migration status

\begin{tabular}{lcl}
\hline & \multicolumn{2}{c}{ Migration Status } \\
\cline { 2 - 3 } $\begin{array}{l}\text { Study } \\
\text { variable }\end{array}$ & Non-migrant & Migrant \\
\hline Mean family size $^{\mathrm{a}}$ & 5.68 & 6.20 \\
Mean age $^{\mathrm{a}}$ \% Male & 24.2 & 24.7 \\
& 49.5 & 44.6 \\
Mean schooling (years) $^{\mathrm{b}}$ & $1.73(3.1)$ & $2.76(4.3)$ \\
\% Completed Grade X or more $^{\mathrm{b}}$ & 3.70 & 7.20 \\
Mean land owned (acres) $^{\mathrm{c}}$ & $0.62(1.49)$ & $2.58(5.23)$ \\
\% Landless $^{\mathrm{c}}$ & 56.9 & 19.4 \\
\% Sale labourc $^{\mathrm{c}}$ & 42.2 & 4.3 \\
\% Muslim $^{\mathrm{c}}$ & 72.4 & 88.5 \\
$\mathrm{~N}$ & 2,926 & 3,193 \\
\hline
\end{tabular}

Note: Standard deviations are shown within parentheses.

${ }^{a}$ Calculated by taking all family members.

${ }^{b}$ Persons aged 6 years or older are considered.

${ }^{c}$ Estimated as family level variable.

\section{RESULTS}

\section{Profile of study women}

The socio-demographic characteristics of the population of both the migrant and non-migrant families are summarised in Table 1. The mean family size is significantly larger in the migrant than the non-migrant households probably because the left behind members tend to live in extended households. The difference in mean age between the migrant and non-migrant family members is insignificant. The proportion of male members is smaller in the migrant than non-migrant families. Mean years of schooling and the level of education are much higher among the migrants than non-migrant families.

The migrant families posses more land than non-migrants in general. Landlessness is also lower among the migrant than non-migrant families probably because the migrant families in the villages invest remittance to procure more lands. On the other hand, members of the large land-owning families are more likely to take the opportunity to migrate than the poor. The migrant families are economically much better-off than the non-migrants as about $\mathbf{4 2 . 2}$ percent of non-migrant families depend on selling manual 
labour for their livelihood compared to only 4.3 percent in the migrant families. Overseas migration is higher among the Muslims than the Hindus. It is not clearly known, however, whether the observed differences in socioeconomic condition between the two groups are the effects of the flow of remittances to the migrant families.

Table 2. Women's position of the left behind by the status and duration of migration

\begin{tabular}{llll}
\hline \multirow{2}{*}{$\begin{array}{l}\text { Type of } \\
\text { families }\end{array}$} & \multicolumn{3}{c}{ Women's Position } \\
\cline { 2 - 4 } & $\begin{array}{l}\text { Decision } \\
\text { making }\end{array}$ & $\begin{array}{l}\text { Education } \\
\text { for girl }\end{array}$ & $\begin{array}{l}\text { Practice of } \\
\text { dowry }\end{array}$ \\
\hline $\begin{array}{l}\text { Non-migrant } \\
\text { Migrant }\end{array}$ & 9.5 & 54.4 & 59.9 \\
$P$-value & 27.1 & 79.9 & 32.0 \\
& $<.01$ & $<.01$ & $<.01$ \\
$\begin{array}{l}\text { Duration of migration } \\
\text { < 5 years }\end{array}$ & & & \\
5 years or more & 28.7 & 78.0 & 38.0 \\
$P$-value & 26.2 & 83.1 & 16.9 \\
\hline
\end{tabular}

ns=Not significant.

\section{Migration and women's position}

Table 2 shows that women's position differs significantly between the migrant and non-migrant families. Decision making, measured as the extent to whether women can decide or actively participate in the decision-making processes within the families, is significantly higher $(p<0.01)$ in the migtant than nonmigrant families. Decision making role among the left behind women, however, does not change much with the duration of migration in the overseas.

Traditionally, women are deprived of getting education in rural Bangladesh compared to men. Sending girls to school is expected to reduce gender inequality in education and, thus, the enrollment of girls in school is considered as an indicator of women's position. This study shows that migrant family members are more concerned for the education of their girls than others (Shah and Arnold, 1985) probably because cultural exchange as a result of international migration have raised the aspirations for the education of their girls. Data also show that the school enrollment among girls increases with the duration of migration (Gilani, 1983) indicating that both the remittance and secular values from overseas may have modified behaviours of the left behind women.

The practice of dowry in Bangladesh villages is common particularly among the poor (Hadi, 1998) although attempts have been made by various agencies to reduce the practice of dowry. While the 
financial capacity to provide dowry is much better among the migrant than non-migrant families, the practice of dowry is lower among the migrant than non-migrant families. The incidence of dowry continues to decline as the duration of migration increases $(p<0.01)$.

Table 3. Differences in women's position between the migrant and non-migrant families by the sociodemographic characteristics

\begin{tabular}{|c|c|c|c|c|c|c|}
\hline \multirow{2}{*}{$\begin{array}{l}\text { Study } \\
\text { variable }\end{array}$} & \multicolumn{2}{|c|}{ Decision making } & \multicolumn{2}{|c|}{ Education for girls } & \multicolumn{2}{|c|}{ Practice of dowry } \\
\hline & Non-migrant & Migrant & Non-migrant & Migrant & Non-migrant & Migrant \\
\hline \multicolumn{7}{|l|}{ Age (years) } \\
\hline$<30$ & 9.1 & 57.7 & 50.0 & 81.0 & 65.0 & 53.3 \\
\hline $30-39$ & 10.9 & 37.2 & 43.5 & 94.3 & 50.0 & 23.5 \\
\hline $40-49$ & 10.7 & 23.4 & 55.4 & 76.5 & 70.8 & 38.5 \\
\hline $50+$ & 7.8 & 17.1 & 55.7 & 75.7 & 59.2 & 28.2 \\
\hline P-value & $n s$ & $<.01$ & $n s$ & $<.10$ & $n s$ & $n s$ \\
\hline \multicolumn{7}{|l|}{ Education } \\
\hline None & 12.1 & 30.4 & 39.0 & 75.3 & 68.5 & 41.9 \\
\hline Some & 5.6 & 24.8 & 71.9 & 82.6 & 47.5 & 24.4 \\
\hline P-value & $<.01$ & $n s$ & $<.01$ & $n s$ & $<.01$ & $<.01$ \\
\hline \multicolumn{7}{|c|}{ Land ownership } \\
\hline Landless & 10.2 & 45.0 & 37.7 & 75.0 & 61.3 & 44.1 \\
\hline Land owner & 8.1 & 22.4 & 71.8 & 81.0 & 59.2 & 28.0 \\
\hline$P$-value & $n s$ & $<.01$ & $<.01$ & $n s$ & $n s$ & $<.05$ \\
\hline \multicolumn{7}{|l|}{ Religion } \\
\hline Muslim & 9.4 & 27.0 & 54.7 & 79.5 & 57.9 & 26.7 \\
\hline Hindu & 9.0 & 25.4 & 52.4 & 82.6 & 65.9 & 55.2 \\
\hline$P$-value & $n s$ & $n s$ & $n s$ & $n s$ & $n s$ & $<.01$ \\
\hline
\end{tabular}

ns=Not significant.

\section{Socio-demographic correlates of women's position}

The differences in the indicators of women's position in both the migrant and non-migrant families by selected socio-demographic factors are shown in Table 3. Women's position as a decision maker does not change much with their age in non-migrant families although the decision making role is lower among older migrant families $(p<0.01)$. It is not known why decision making capacity shows a negative association with the education of women. Educated women, who are mostly from the upper classes in the community, might have been the subject of patriarchal domination, a traditional system more strictly followed in the relatively well-off classes in the rural communities in Bangladesh. For the same reason, land ownership also shows negative association with the decision making role of women. Data clearly 
indicate that religious belief has no association with the decision making capacity of women. The attitudes towards female education differ by age of women only marginally. As expected, education of women and land ownership are positively associated with the education of girls in both migrant and nonmigrant families. Religion has no association with the preference of education for children. The practice of dowry in marriages does not show any relationship with age of women in both migrant and nonmigrant families. The dowry practice has negative association with the education of women and land ownership of the families. The practice of dowry is significantly higher among the Hindus than the Muslims in migrant families.

Table 4. Odds ratios of the effects of migration to predict indicators of women's position

\begin{tabular}{|c|c|c|c|}
\hline \multirow{2}{*}{ Predictor } & \multicolumn{3}{|c|}{ Women's Position } \\
\hline & $\begin{array}{l}\text { Decision } \\
\text { making }\end{array}$ & $\begin{array}{l}\text { Education } \\
\text { for girl }\end{array}$ & $\begin{array}{l}\text { Practice of } \\
\text { dowry }\end{array}$ \\
\hline \multicolumn{4}{|l|}{ Duration of migration } \\
\hline Non-migrant & 1.00 & 1.00 & 1.00 \\
\hline$<5$ years & $3.39 * *$ & $1.96^{*}$ & 0.62 \\
\hline 5 years or more & $3.14^{* *}$ & $2.09 *$ & $0.23^{* *}$ \\
\hline \multicolumn{4}{|l|}{ Socio-demographic } \\
\hline Age & $0.96^{*}$ & 1.00 & 0.98 \\
\hline Year of schooling & $0.87^{* *}$ & 1.04 & $0.88 * *$ \\
\hline Land ownership & $1.01 * *$ & 1.00 & 1.00 \\
\hline Religion ( $\mathrm{rc}=$ Muslim) & 1.04 & 0.79 & $2.16^{*}$ \\
\hline - 2 Log likelihood & 835.7 & 504.6 & 412.2 \\
\hline Pseudo R squared & 0.20 & 0.12 & 0.26 \\
\hline $\begin{array}{ll}* & p<0.05 \\
* * & p<0.01\end{array}$ & & & • \\
\hline
\end{tabular}

\section{Net effects of migration on women's position}

The influence of international migration in terms of injecting new and secular ideas on the left behind women on selected dimensions of women's position is estimated by employing logistic regression analysis (Table 4). The absence of men has not only led some migrants' wives to take new role from male domains (Gardner, 1995), but that women's decision making capacity has significantly $(p<0.01)$ improved. The probability in raising decision making is 3.39 times more likely among women where the migrants are living abroad for at least some years compared to the women of non-migrant families when age, years of schooling, land ownership and religious belief are controlled. However, the estimated improvement in decision making stabilises after some time and has no association with the duration of 
migration. Age of women has a significant negative association with decision making probably because older women, having longer exposure to traditional culture, are less likely to accept new behaviour. As explained earlier, educated women, mostly from the upper classes, have limited scope to modify their traditional behaviour. Land ownership has significant positive association with the decision making among women. Religious belief has no association with decision making. In the absence of men, women in the migrant families play wider roles in family affairs and are less under the domination of men (Khafagy, 1982) that would have substantially raised their decision-making capacity (Shah and Arnold, 1985).

The chance for girls to be enrolled in the school is 96 percent higher among the migrant than nonmigrant families even when socio-demographic factors of women such as age, years of schooling, land ownership and religion are taken into consideration. The socioeconomic confounding factors have no significant association with the education for girls. The probability of school enrollment improves further with the duration of migration in overseas. It is argued that the acceptance of gender equity in education among the migrants might have motivated them to send their girl children to school. The pattern of relationship suggests that the potential to reduce gender bias in education increases with the duration of migration in overseas.

International migration reduces the practice of dowry when most other potential predictors are controlled. The reduction is, however, significant only when the duration of migration is 5 years or more $(\mathrm{p}<0.05)$. The practice of dowry, particularly among the poorer section, is widespread in Bangladesh (Amin and Hadi, 1998). While education has significant negative association, dowry has remained as a traditional practice particularly among the Hindus $(p<0.01)$. As the Hindu inheritance law does not allow married women to receive parental property, the practice of dowry is 2.16 times higher among the Hindus than Muslims. The dowries are culturally acceptable to the wider community except educated and socioeconomically better off section who considers it as wrong, unjust and should be prohibited. Controlling the role of a number of confounding factors, the study supports the assumption that the diffusion-effect of secular values from the overseas reduces the practice of dowry among migrant families. The capacity to spend money in the form of dowry in migrant families is higher because the migrant families are financially better able to save money than non-migrant families. The incidence of dowry declines even when the financial capacity increases with the duration of exposure $(p<0.01)$.

\section{DISCUSSION}

The economic impacts of international migration relating to the significance of remittances have been widely debated. As overseas migrants are rarely generators of productive investment of their remittances in their home communities (Jones and Pardthaisong, 1999; Hadi, 1999), the role of remittance might be 
viewed as a determinant of the behavioural aspects of change. Many overseas migrants visit their families at home on a regular basis and, thus, the interaction between the migrants and their family members is likely to influence the later in many ways. International migrants not only raise the standard of living of their left behind kin through injecting remittances but also modify their social behaviours through the diffusion of secular ideas to the traditional values of the sending communities.

The effects of behavioural aspects of overseas migration in changing the position of left behind women in the sending communities are assessed in this research. The magnitude of the change of women's position depends on the duration of influence of secular values received by the left behind women. The study has shown that individual and socio-economic characteristics of women also significantly influence their position although the influence has been much more pronounced among the women in migrant than non-migrant families.

In the patriarchal social norm, it is expected that women should have limited decision making role and limited control over resources in the family. The position of women, however, is not static and that the traditionalism is no longer the part and percel of contemporary circumstances in Bangladesh. This study shows that the infusion of remittances and secular values from overseas has the potential to undermine the traditional domains of men and significantly modify gender role. The position of Bangladeshi women in the migrant families and in the communities are influenced by their relative control of resources (Gardner, 1995). In the absence of husband or other adult men, women enjoy increased freedom and autonomy in managing their households (Colfer, 1985; Khafagy, 1982; Shah and Amold, 1985; Gulati, 1983). In many occasions, they are forced to play additional domestic role. The prolonged absence of men encourages women to take major roles in managing the household (Gulati, 1983), enhances women to grow independently, helps develop new interest and discover hidden potentials (Hadi, 1999; Gardner, 1995; Go et al., 1983). One woman has reflected, "As my husband went off, I had no choice... Now, I look after my family by myself. I have become used to it." The newly gained position of women in the migrant families is the result of separation from spouses and the problems experienced in managing the families (Hadi, 1999). The typical pattern of the Bangladeshi left behind families is to form an autonomous sub-unit within the extended households. Such nuclearisation of the families helps women to gain more control over their households. In the nuclear families, women have better control over domestic affairs compared to the extended families with in-laws (Gardner, 1995). "Before, I had to ask my parents-in-law for everything. Now, the only person I need to ask is myself', as one woman has expressed her feelings.

Recognition of female education in a traditional community is an important indicator of the change of women's position. The increased aspiration for the education of their daughters with the duration of exposure to migration suggests that both the remittances and secular values have modified behaviours 
relevant to female education (Hadi, 1999; Parasuram, 1986; Abbasi and Irfan, 1983). One woman has informed, "My husband wants me to send my daughter 10 school along with my sons" indicating the acceptance of gender equity in educating children among rural women.

Dowries are not generally acceptable to the elite families in Bangladesh. Although the migrant families are more capable of paying dowries than non-migrants, the practice of dowry is relatively lower in the migrant families (Gulati, 1983). The most plausible explanation of the negative association of migration with dowry is the role of newly gained prestige among migrant families as a result of being financially better-off among their neighbours. The diffusion-effect of secular values from overseas has modified the cultural behaviours of the practice of giving dowries in marriages. "We have money but we don't provide or accept dowries. Why should we? It's not good." Such feeling is a clear reflection of the rejection of dowries among the migrant families.

The question remains whether the change of women's position is temporary as a result of the absence of male members in the households. The power of women is always dependent upon access to resources and male support. Even while the husbands are away for many years, important decisions such as the sale or acquisition of land, the building of a new house or migration of another family member, etc. remain the domain of husbands (Gardner, 1995). Thus, it is not certain whether women are forced to play this role or they have really able to change their position. While it is quite possible that the new role will not sustain once their husbands return, it is expected that some of the secular values adopted and practised will continue in future. The contribution of social and behavioural aspects of migration in modifying women's position will largely depend on the context. The study concludes that south-north migration can play an important role in modifying gender role of the left behind women by enhancing their position in their families and modifying the cultural values in a traditional community. 


\section{NOTES}

1. Secular idea means modern, progressive and scientific approach in understanding and explaining any issue, event or change, etc.

2. Women's position is the process of improving her role and status within the family. Three indicators are used to measure women's position. These are women's decision making capacity, enrollment of female children and the practice of dowry in marriages.

3. Women's decision making capacity is measured whether a woman can make her own decision or can actively participate in the decision making processes within the family. Decision issues include: amount of money to be spent for the family members, type of treatment to be given for herself or her children, whether or when to visit natal home or other places, during festivals, and whether or how much money should be lend to or borrowed from others.

4. Enrollment of female (6-15 aged) children is considered an indicator of gender equity. Education for girl is measured by asking what proportion of female children are enrolled in school during the time of survey.

5. Giving cash or gifts as dowries in marriages is widespread in rural Bangladesh although a smaller section of the community considers it as wrong, unjust and should be prohibited. The practice of dowry is measured by asking whether any member of the family received or provided money or asset in marriages during the last five years.

\section{ACKNOWLEDGEMENTS}

This research was supported by the Strengthening Research and Evaluation Activities in BRAC Project of the Ford Foundation, Dhaka, Bangladesh. The author is grateful to the respondents who were kind enough to provide information for this research and wishes to thank Professor Huw Jones of the University of Dundee and Mr. Hasan Shareef Ahmed of BRAC for his constructive criticisms and comments of the earlier version of the paper. 


\section{REFERENCES}

Abbasi $\mathrm{N}$ and Irfan M. 1983. Socioeconomic effects of international migration on the families left behind. Paper presented to the Conference on Asian Labor Migration to the Middle-East, September 1983, Honolulu.

Amin FD, Hadi A. 1998. Micro-credit programs, women's empowerment and change in nuptiality in Bangladesh villages. Paper presented at the 1988 Annual Mecting of the Population Association of America (PAA), 2-4 April. Population association of America: Chicago.

Colfer C. 1985. On circular migration: from the destaff side. In Labour Circulation and the Labour Process, G. Standing (ed.). Croom Helm: London.

Davin D. 1998. Migration and rural women in China: A look at the gendered impact of large-scale migration. Journal of International Development 8: 655-65.

Dawson 1995. Women, men and Merantau: shifting gender relations in transmigrant households. Paper prepared for the Conference on Indonesian Women in the Household and Beyond, 25-29 September, Leiden.

Gardner K. 1995. Global Migrants, Local Lives. Travel and Transformation in Rural Bangladesh. Clarendon Press: Oxford.

Gilani I. 1983. Overview of stocks and flows of migrants and the social and familial impacts on communities and households in districts of high labor migration. Paper presented at the Conference on Asian Labor Migration to the Middle East, 19-23 September. East-West Population Institute: Honolulu.

Go SP, Postrado LT, Jumere PR. 1983. The effects of international contract labor (Philippines). Vol. I, Integrated Research Center. De La Salle University: Manila.

Gulati L. 1983. Impacts of male migration to the Middle East on the household: some evidence from Kerala, India. Paper presented at the Conference on Asian Labor Migration to the Middle East, 19 23 September. East-West Population Institute: Honolulu.

Hadi A. 1998. Early marriage, bride price and the practice of dowry in Bangladesh villages. Watch Report No 35. BRAC: Dhaka.

Hadi A. 1999. Overseas migration and the well-being of those left behind in rural communities of Bangladesh. Asia-Pacific Population Journal 14: 43-58.

Hugo G. 1997. Migration and female empowerment. Paper presented at the IUSSP Seminar on Female Empowerment and Demographic Processes: Moving Beyond Cairo. April 21-24. IUSSP: Lund, Sweden.

Islam M, Chowdhury H, Salehuddin M, Dutta JP, Ali M, Hoque AKE. 1987. Overseas Migration from Rural Bangladesh: A Micro Study. University of Chittagong: Chittagong.

Jones H, Pardthaisong T. 1999. The impact overseas labour migration on rural Thailand: Regional, community and individual dimensions. Journal of Rural Studies 15: 35-47. 
Khafagy FA. 1982. Socio-economic impact of emigration from El-Quebabat village. Population Studies 61: 39-45.

Parasuram S. 1986, Migration and its effect on family. Indian Journal of Social Work 47: 15-22.

Russell SS. 1997. International migration: implications for the World Bank. Working Paper, Human Capital Development and Operations Policy. World Bank: Washington, D.C.

Shah NM, Arnold F. 1985. The non-economic consequences of Asian labour migration to the Middle East. International Population Conference, Vol. 3. International Union for the Scientific Study of Population (IUSSP): Liege.

United Nation, 1985. Expert Group Meeting on International Migration in Asia and the Pacific. ESCAP: Bangkok. 